Компресорні тепловикористальні холодильні машини, які працюють за циклом Чистякова-Плотнікова, споживають утилізоване скидне тепло енергетичних установок як первинну енергію для виробництва холоду різного температурного потенціалу, чим забезпечують економію паливно-енергетичних ресурсів. Розвиток та удосконалення машин пов'язано з використанням нових робочих речовин. В роботі запропоновано спосіб вибору робочих речовин для машини з агрегатом «турбіна-компресор» на засадах таких фундаментальних характеристик, як енергозбереження та екологічна безпека. Вивчено взаємовплив властивостей R134a, R290, R401a, R410a, R407a, R507, R600, R717 та конструктивних параметрів компресора $i$ турбіни у заданому температурному режимі термодинамічного ииклу за умови рівності потужностей турбіни і компресора. У дослідженні використано параметри натурного взірия агрегату «турбіна-компресор» $i$ результати його експериментальних досліджень на попередніх робочих речовинах.

На окремому прикладі здійснено вибір робочих речовин системи холодопостачання конкретного споживача (фруктосховища) з малою енергетичною установкою із заданими температурним режимом виробнищтва холоду $i$ конструктивними параметрами агрегату. Запропонований до аналізу безрозмірний критерій рівноваги встановив й оцінив залежність конструктивних параметрів агрегату та умови його роботи від властивостей робочої речовини та область раціонального застосування будь-якої робочої речовини для конкретної конструкцї̈ агрегату. Компресорна тепловикористальна холодильна машина на вивчених робочих речовинах здатна ефективно виробляти холод у системі тригенерації малої енергетичної установки

Ключові слова: тепловикористальна холодильна машина, агрегат «турбіна-компресор», робоча речовина, термодинамічні властивості

\section{SELECTION OF NEW WORKING FLUIDS FOR A HEAT-USING COMPRESSION REFRIGERATING MACHINE WITH THE BLOCK «TURBINE- COMPRESSOR»}

\author{
L. Moroz y u k \\ Doctor of Technical Sciences, Professor* \\ B. Hrudk a \\ Assistant* \\ E-mail: bogdangennadievich@gmail.com \\ O. Yuzh a k ova \\ $\mathrm{PhD}$, Associate Professor \\ Department of Ukrainian studies \\ and Linguodidactics** \\ E-mail: uzhakoff@te.net.ua \\ *Department of cryogenic technique** \\ **Odessa National Academy \\ of Food Technologies \\ Kanatna str., 112, Odessa, Ukraine, 65039
}

\section{Introduction}

Power machines (heat machines), refrigerating machines and heat pumps belong to the class of energy converting systems. Heat machines convert primary thermal energy into electrical, mechanical, and thermal energy. Useful effect of refrigerating machines consists in obtaining cold of various temperature potentials, heat pumps generate heat of various temperature potentials utilizing electrical, thermal, or mechanical energy. Accordingly, refrigerating machines and heat pumps are always associated with heat machines. As concerns working fluids involved in all processes, heat and refrigerating machines (heat pumps) can have different working fluids. In this case, the refrigerating machines (heat pumps) use electrical or mechanical energy and are called compression machines. Heat and refrigerating machines (heat pumps) can have the same low-evaporating working fluids (pure or a mixture) in accordance with the operating conditions of the refrigerating machine (heat pump). At the same time, a complex thermodynamic cycle is realized consisting of two interrelated simple cycles: direct and reverse. Such machines use thermal energy and are called heat-using machines.
Consumption of primary energy is the main indicator of energy consumption perfection for all machines, therefore saving of fuel and energy resources is the main problem for each of them. Solution of this problem for heat machines is associated with utilization of waste heat with various temperature potentials. For refrigerating machines and heat pumps, one of solutions consists in development and improvement of heat-using machines with expansion of the possibility of using heat of any temperature potential as the primary energy.

The group of heat-using machines includes absorption, ejector and compression machines and hybrid machines on their basis. Absorption machines perform thermochemical compression and their working fluids are the mixtures that determine nature of the process. In ejector machines, mechanical compression occurs in a jet apparatus, an ejector. The machines work with any low-evaporating working fluids. In compression machines, mechanical compression is carried out in turbocompressors. Compressors are driven by turbines operating on the same working fluids as the refrigerating machines. Machines use low-evaporating fluids having a relatively high normal evaporating point and a large molecular weight as working fluids. Selection of a working fluids is largely determined by rotational speed of the compressor 
shaft (up to 2,000 rps). Compressors possess all advantages of high-speed compressors: small size and weight. Among the heat-using machines, various compression machines are the most energy efficient.

In the late 1990s and early 2000s, studies of refrigerating machines, and in particular heat-using ones, were suspended for a number of objective reasons and, first of all, in connection with appearance of international, regional and national acts declaring a ban on known widely used working fluids. Currently, the studies are being intensively renewed. There were two reasons for this. The world market of refrigerating machines offers a large number of new working fluids, both pure and mixtures, natural and synthesized. The situation in the market is rather complicated: insufficiently studied in scientific terms working fluids are often offered for use and a change in offers is observed. The studies of refrigerating machines with piston, rotary, screw and spiral compressors are based on selection of working fluids and the offered new diagram-cycle related solutions for machines take into account energy saving and environmental safety.

The growing production of cogeneration installations has become an impetus for development and improvement of all types of heat-using refrigerating machines. Various schemes of using heat being a direct emission of heat machines form the basis of the cogeneration technologies. Various types of modern power machines of small and fluid capacity are produced in combination with heat-using means. Combination of a cogeneration machine and a heat-using refrigerating machine creates a system of trigeneration, that is, simultaneous production of electricity, heat and cold with the use of one type of primary energy. It should be noted that the year-round air conditioning (seasonal heating and cooling) is the first-order utilizer in many countries and ensures stable operation of the trigeneration system.

The small-scale power generating systems that solve problems of settlements remote from central energy supply systems and independent small enterprises, in particular agricultural ones, are the examples of existing trigeneration systems. They are most demanded but have too little technical information on development.

Taking into account the foregoing, theoretical studies of various types of heat-using machines in the trigeneration regimes, their diagram-cycle solutions based on selection of new working fluids, are topical. The study results will preliminarily establish not only energy efficiency and environmental safety of the object under consideration but also create an idea of a number of engineering factors that will ensure the machine operability.

\section{Literature review and problem statement}

Scientific and technical information on creation of a new generation of heat-using refrigerating machines and the search for new working fluids for these machines is contained in the studies of the last 10-15 years. The most known and studied are the absorption machines. Aqueous solution of lithium bromide and a water-ammonia solution remain to be the main widely used and promising working fluids. Lithium bromide machines reached the limit of perfection. Their practical application is limited to air conditioning systems both independent and in the combination with trigeneration machines for operation of large construction projects for various purposes and for the provision of technological processes for industrial enterprises with various process temperature levels [1].
The water-ammonia solution is the most promising. All new diagram-cycle solutions for water-ammonia machines are associated with practical implementation of earlier theoretical studies. An absorption-diffusion machine is presented in [2] as an element of the system of cooling pressurized air in diesel engines. A hybrid absorption-compression machine with a large scale of temperature variation of a heat source or several heat sources with different temperatures was investigated in [3]. The resorption cycle for the trigeneration system was analyzed in [4]. Absorption machines are oriented to work with heat sources with a relatively low temperature potential $\left(90 \ldots 250{ }^{\circ} \mathrm{C}\right)$ which relates to the properties of mixtures. The conversion factor for absorption machines is $C O P=0.3 \ldots 0.8$.

Ejector machines work with various working fluids and have a large range of productivity. More than 30 various working fluids, various diagram-cycle solutions and designs of ejectors were subjected to study. Currently, use of these machines is limited by special conditions: air conditioning in small trigeneration systems or in the systems powered by individual renewable energy sources with a temperature potential of $100 \ldots 140{ }^{\circ} \mathrm{C}$. The conversion factor is $C O P=0.26 \ldots 0.3$. A new line of the use of ejector machines is presented in $[5,6]$. Hybrid cascade machines are considered in both studied: a hybrid with the compression machine working on $\mathrm{CO}_{2}$ in the lower cascade and the ejector machine working on R245ca, R600, R601b and R717 in the upper cascade. The new working fluids and diagram-cycle solutions have ensured growth of the machine efficiency and expansion of the temperature scale of produced cold.

Compression refrigerating machines are the latest among heat-using machines. They have a 60-year history. Their formation was rather complicated at various periods of development of refrigeration technology and associated with the scientific school of the Odessa State Academy of Refrigeration (now Odessa National Academy of Food Technology, Ukraine). The issues of theory and results of pilot-demonstration and experimental studies are presented in [7-10].

Thermodynamic cycle of a machine with the same working fluids in a compressor and a turbine was named after the authors' names: Chistiakov-Plotnikov cycle. The turbine and compressor were made in a form of a compact turbinecompressor block with arrangement of wheels on one shaft, the stuffing box seal was unnecessary. In most cases, centrifugal compressor and radial centripetal turbine were built single-stage. The machines were an integral part of the centralized air conditioning system for dry-cargo ships, tankers, seiners with utilization of the waste heat of ship power machines, submersible devices, and ground transport facilities for special purposes, cooling compressed air of diesel locomotives and ships. Another line in the use of small heat-using machines was agricultural production associated with construction of large vegetable and fruit storage facilities with individual power machines [11]. R11, R12, R113, R114 and $\mathrm{R} 21$ were used as working fluids in the machines.

Renewal of the studies on the heat-using compression machines was caused by two reasons mentioned earlier. The first working fluids proposed for consideration was carbon dioxide, $\mathrm{CO}_{2}$, one of the most popular working fluids in power generating and refrigerating machinery. On the basis of thermodynamic analysis, a new diagram-cycle solution of a heat-using machine was introduced in [12] and the range of operating temperatures and pressures was established which ensured a high energy efficiency of the machine. A theoretical study of the diagram-cycle solution of a low-temperature heat-using machine working on $\mathrm{CO}_{2}$ was performed in [14]. Paper [15] 
considers the issues of creation of trigeneration systems using a supercritical cycle of a refrigerating machine working on $\mathrm{CO}_{2}$.

Lack of information in current technical literature is the evidence that the studies on creation of low-capacity compression machines were exclusive, designed for a narrow circle of special consumers and built on existing engineering base and working fluids. Renewal of scientific studies in the field of compression machines is necessary to meet the worldwide demand of small-scale power generation systems. Currently, trigeneration systems include absorption refrigerating machines that have limitations on the temperature regimes, working fluids and operating conditions. Expansion of temperature boundaries and increase in energy efficiency of cold production, expansion of the competitive environment in the class of heat-using machines is associated with development of compression machines based on the use of new working fluids. Therefore, this line of studies is promising.

\section{The aim and objectives of the study}

The study objective was the selection of new working fluids for the heat-using compression refrigerating machine operating in the Chistiakov-Plotnikov cycle. Selection is based on the general method of comparative evaluation of thermodynamic properties and determines practical feasibility of realization and implementation of new technical solutions.

To achieve the objective, it was necessary to solve the following tasks:

- to conduct a thermodynamic analysis of the Chistiakov-Plotnikov cycle with various working fluids;

- to analyze the turbine and compressor operation as independent elements of the turbine-compressor block with specified design values depending on thermodynamic properties of the working fluids;

- to demonstrate on a particular example the method of selection of working fluids depending on the turbine and compressor design values.

\section{Thermodynamic analysis of the Chistiakov-Plotnikov cycle}

The complex cycle of any heat-using machine consists of two simple cycles: direct (power) and reverse (refrigeration), with three heat sources: with high $\left(T_{H O T}\right)$, average $\left(T_{A V}\right)$ and low $\left(T_{C L D}\right)$ temperatures.
The theoretical cycle of the machine is based on the thermodynamic Carnot-Carnot cycle (power: 1-2-3-4 and refrigeration: 8-5-6-7) and is shown in Fig. 1, $a$.

The corresponding theoretical technological diagram of the machine includes two loops: a power loop with heat exchangers (HE1) and (HE2), a turbine (T), a compressor $(\mathrm{C} 2)$ and a refrigeration loop with heat exchangers (HE2) and (HE3), a compressor (C1) and an expander (E) (Fig. 1, $b$ ). The heat exchanger (HE2) belongs to both diagrams and indicates presence of a single working fluids in the machine. To illustrate transfer of torque and the equality of works in the power and refrigerating cycles, the turbine, compressors and expander are shown graphically mounted on a common axis.

For simple cycles, the heat source with an average temperature $T_{A V}$ is a common case, its temperature is equal to the ambient temperature. Of the three heat sources for the heat-using machines, two can be set arbitrarily and the third as a function of the first two. According to [16], for the theoretical cycle:

$$
T_{H O T}=\left(T_{C L D} \cdot T_{A V}\right) /\left(2 T_{C L D}-T_{A V}\right) .
$$

Temperatures $T_{C L D}$ and $T_{A V}$ are known proceeding from the machine purpose. Temperature $T_{\text {HOT }}$ is determined by the type of the high-temperature source. It can be a combustible fuel, used heat of power machines, secondary industrial and natural renewable energy resources. Then, according to equation (1), there is a minimum temperature $T_{H O T}$ at which a particular heat-using machine can have a practical realization. Energy balance of the machine (Fig. 1,b) is written in the form:

$$
Q_{C L D}+Q_{H O T}+W_{C 2}+Q_{C 1}=Q_{A V}+W_{T}+W_{E}
$$

Taking temperatures $T_{H O T}, T_{C L D}$ and $T_{A V}$ constant and heat transfer in the heat exchangers ideal, represent the cycle taking into account the real single working fluids (Fig. 1, c). Conditions are created in the machine at which processes in the power and refrigerating cycles occur in a two-phase region. Phase transformations of the working fluids take place in the heat exchangers: process 1-2: evaporating in (HE1) of the power loop at $T_{\mathrm{HOT}}$, processes $3-4$ and 5-6: condensation in (HE2) at $T_{A V}$, process 7-8: evaporating in (HE3) of the refrigerating loop at $T_{C L D}$.
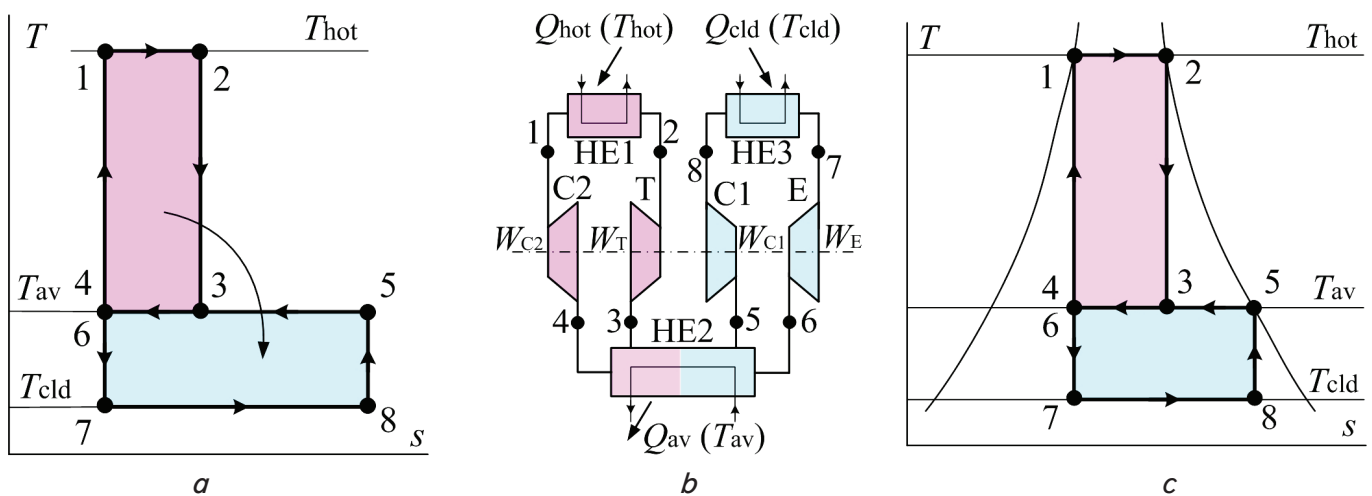

Fig. 1. Theoretical cycle and diagram of a heat-using refrigerating machine: Carnot-Carnot sample cycle $(a)$; technological diagram (b); theoretical cycle with a real working fluids (c) 
On the basis of the theory of steam compression refrigerating machines, such a cycle cannot be practically realized [16]. To realize the cycle, it is necessary to replace the heat exchanger (HE1) with the generator $(G)$, the heat exchanger (HE2) with the condenser (CD), the heat exchanger (HE3) with the evaporator (EV), the expander (E) with the throttle (TH), the compressor (C2) with the pump (P). The processes of isothermal supply and removal of heat should be replaced by isobaric ones, expansion processes in the turbine $(\mathrm{T})$ and compression in the compressor (C1) transferred to the superheated steam region. The machine cycle and diagram take the form shown in Fig. 2.
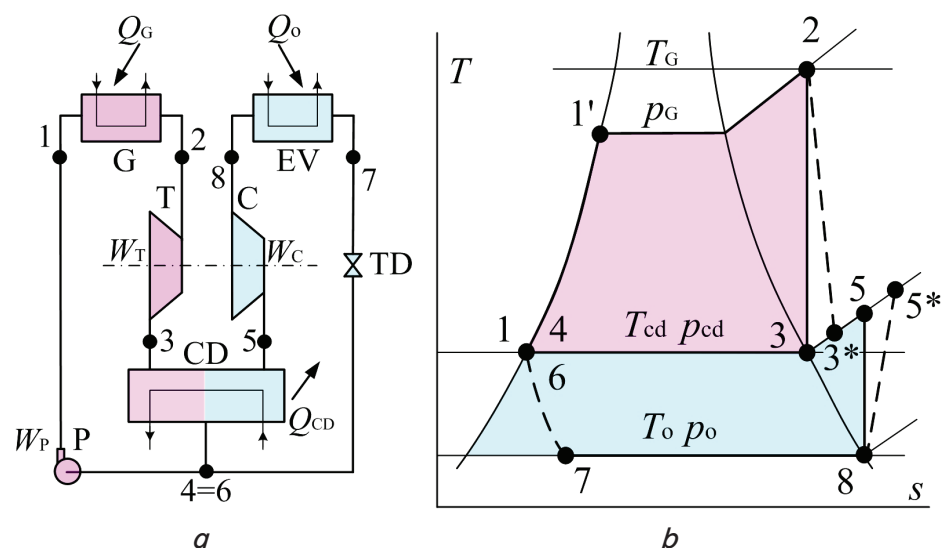

Fig. 2. Real diagram and cycle of a heat-using refrigerating machine: technological diagram $(a)$; real cycle in the diagram $T$-s $(b)$; generator G; evaporator EV; turbine T; compressor C; condenser CD; pump P; throttling device TD

Thus, the machine operates at three pressure levels: $p_{0}=f\left(T_{0}\right), p_{c d}=f\left(T_{c d}\right), p_{G}$ is an independent parameter provided that $p_{G}<p_{c r}$ for a given working fluids. The maximum temperature in the generator $T_{G}$ is determined by the properties of the high-temperature source $\left(T_{G} \approx T_{\text {Hот }}\right)$. The energy balance of the real machine (Fig. 2, $a$ ) is written as:

$$
Q_{0}+Q_{G}+W_{P}=Q_{C D}
$$

where $Q_{0}$ is refrigerating capacity, $Q_{G}$ is thermal load on the generator; $W_{P}$ is the pump work; $Q_{C D}$ is thermal load on the condenser.

The choice of working fluids and comparative thermodynamic analysis is carried out in the following order:

- choose schematic diagram of the machine;

- construct a corresponding cycle taking into account the selected working fluids;

- determine according to the cycle all necessary thermal and caloric parameters at the nodal points;

- reduce everything to $1 \mathrm{~kg}$ of the working fluids circulating in the refrigerating cycle.

For the first test of the method, the real cycle of the heat-using machine is formed from two Planck cycles: power and refrigeration cycles (Fig. 2, $b$ ). In this case, state of the working fluids at suction to the compressor (C), exit from the turbine (T), before the pump (P) and the throttle device (TD) are unambiguously defined [17]. In the $T-s$ diagram, the real cycle is represented by two loops: 1-1'-2-3-4 and 5-6-7-8. Specific characteristics of the cycle are determined for concrete working fluids and temperature regimes:
- specific heat load on the generator:

$$
q_{G}=h_{2}-h_{1}, \mathrm{~kJ} / \mathrm{kg}
$$

- specific mass cooling capacity:

$$
q_{0}=h_{8}-h_{7}, \mathrm{~kJ} / \mathrm{kg}
$$

- adiabatic work of the compressor:

$$
w_{C D}=h_{5}-h_{8}, \mathrm{~kJ} / \mathrm{kg}
$$

- adiabatic work of the turbine:

$w_{T}=h_{2}-h_{3}, \mathrm{~kJ} / \mathrm{kg}$;

- real work of the compressor:

$w_{c r}=w_{C} / \eta_{C}, \mathrm{~kJ} / \mathrm{kg}$

- real work of the turbine:

$w_{T r}=w_{T} \cdot \eta_{T}, \mathrm{~kJ} / \mathrm{kg}$,

where $\eta_{C}, \quad \eta_{T}$ are the adiabatic efficiency of the compressor and the turbine, respectively.

For compression and expansion processes, it is necessary to meet a condition of equality of the turbine and the compressor capacities $N_{C}=N_{T} \cdot \eta_{M E C H}$. Taking into account the mass flow rates in power. $M_{T}$, and refrigerating, $M_{C}$, loops, efficiency of the turbine and the compressor and the mechanical efficiency $\left(\eta_{M E C H}\right)$ of the turbo block, obtain the following:

$$
M_{C} \frac{w_{C}}{\eta_{C}}=M_{T} w_{T} \eta_{T} \eta_{M E C H},
$$

where $M_{C}$ is the mass flow in the refrigerating loop:

$$
M_{C}=Q_{0} / q_{0}, \mathrm{~kg} / \mathrm{s} \text {. }
$$

Multiplicity of circulation, $a$, or the mass flow through the turbine related to $1 \mathrm{~kg}$ of mass flow through the compressor, is represented by the expression:

$$
a=w_{C} / w_{T} \eta_{T} \eta_{C} \eta_{M E C H} .
$$

The $C O P$ of the heat-using compression machine is defined in analysis of the thermodynamic cycle as:

$$
C O P=\frac{q_{0}}{q_{G} \cdot a}=\frac{\eta_{C} \eta_{T} \eta_{M E C H} w_{T} \cdot a}{w_{C}} .
$$

Typical computer programs, for example, CoolPack Refrigeration Utilities and its databases, are ordinarily used to calculate cycle characteristics. However, for clarity, calculations in a comparative analysis should be accompanied by depiction of cycles in the state diagrams $T-s$ and $p$ - $h$.

\section{The turbine-compressor block}

Fig. 3 represents one of the designs of the low-consuming turbine-compressor block. The block is designed to work 
in the Chistiakov-Plotnikov cycle for production of cold and as a structural element of a hybrid absorption-compression machine. Cooling capacity of the machine with this block is $15 \ldots 100 \mathrm{~kW}$ depending on operating temperature regimes. The compressor represents a diffuserless stage with a runner of a pump type. Design values of the runner: outer dia.: $d_{2}=135 \mathrm{~mm}$, internal dia.: $d_{1}=60 \mathrm{~mm}$, inlet blade angle: $\beta_{1}=26^{\circ}$, outlet blade angle: $\beta_{2}=15^{\circ}$, number of blades $z: 8$ [7].

The turbine consists of a runner 2 of a radial-axial type, an inlet chamber and a guiding diaphragm. Design values of the turbine: the runner outer diameter $d_{2}=90 \mathrm{~mm}$, the runner inner diameter $d_{2}=40 \mathrm{~mm}$, inlet blade angle $\beta_{1}=42.5^{\circ}$, outlet blade angle $\beta_{2}=30^{\circ}$, number of blades $z=18$. Weight of the block: $26 \mathrm{~kg}$, overall dimensions: $400 \times 245 \times 355 \mathrm{~mm}$. The block uses gas-static supports 4 working on the working fluids and, as a result, the machine operates on any working fluids without lubrication.

In the joint solution of equations (14) and (15), after mathematical transformations, dimensionless equilibrium criterion $(P)$ is obtained:

$$
P=\frac{\frac{\Delta h_{T}}{\Delta h_{C}}\left(\frac{v_{2 T}}{v_{1 C}}\right)^{0.4} \frac{1}{\left(\eta_{T} \eta_{C} \eta_{M E C H}\right)^{0.4}}}{1.51\left[\psi\left(1-\rho_{T}\right)\right]^{0.6}\left(\varphi \frac{\lambda_{T}}{\lambda_{C}}\right)^{1.2}}=1 .
$$

The numerator represents a mathematical complex characterizing thermodynamic properties of the working fluids, the denominator is a mathematical complex characterizing the design values of the block.

Introduction of the dimensionless equilibrium criterion $(P)$ makes it possible to evaluate dependence of the design values of the block on thermodynamic properties of the working fluids, conditions of its work and the field of rational use of any working fluids for a particular design of the block.

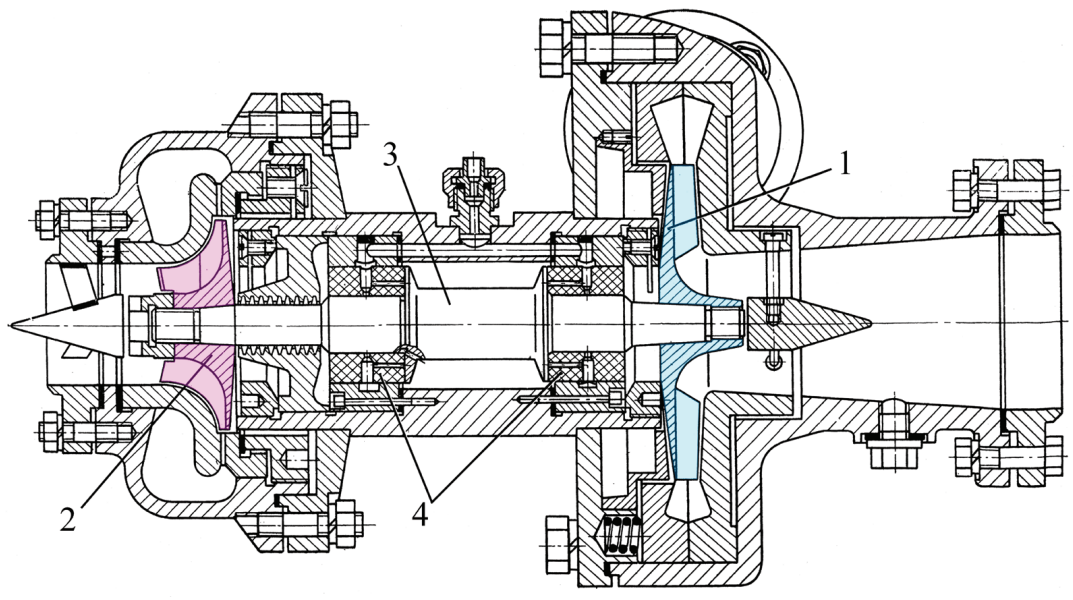

Fig. 3. The turbine-compressor block: compressor runner 1; turbine runner 2; shaft 3; gas-static supports 4

\section{The example of selection of a working fluids for the turbine- compressor block}

As an example, a fruit storage facility was used as a typical cooled object with a constant year-round temperature regime equipped with a small heat power machine with a heat utilizer operating according to the ChistiakovPlotnikov cycle. Eight working fluids were used for analysis: R134a, R290, R401a, R410a, R407a, R507, R600, R717. The input calculation data are given in Table 1.

Table 1

Mass flows of the working fluids in the turbine, $M_{T}$, and the compressor, $M_{C}$, taking into account real design values are determined from the equation of flow continuity [7]:

- for the turbine:

$$
M_{T}=\frac{220 \cdot 10^{6} \lambda_{T}^{3}\left(1-\varepsilon_{T}^{2}\right) \varphi^{3} x^{3} \operatorname{tg} \beta_{2 T}}{B_{T} n_{T}^{2} v_{2 T}}\left[\left(1-\rho_{T}\right) \Delta h_{T}\right]^{1.5}
$$

- for the compressor:

$$
M_{C}=\frac{78 \cdot 10^{6} \lambda_{C}^{3}\left(1-\varepsilon_{C}^{2}\right) \operatorname{tg} \beta_{1 C}}{B_{C} n_{C}^{2} v_{1 C}}\left[\frac{\Delta h_{C}}{\psi}\right]^{1.5}
$$

where $n$ is the shaft rotation speed, $1 / \mathrm{s} ; m$ is the design value; $x$ is the relative peripheral speed of the turbine rotation; $\lambda$ is the ratio of the inner diameter of the wheel to the outer diameter; $\varphi$ is the velocity coefficient of the nozzle diaphragm; $\rho$ is the degree of reactivity; $\psi$ is the thrust coefficient; $\eta$ is the adiabatic efficiency; $v_{3}, v_{8}$ are specific volumes of the working fluids vapor at the outlet of the turbine and at the inlet to the compressor.

Given mounting of the elements on one shaft, it can be assumed that $\beta_{2 T}=\beta_{1 C}, m_{T}=m_{C}$.

Input parameters
\begin{tabular}{|l|c|c|}
\hline Evaporating temperature & $T_{0}$ & $-6{ }^{\circ} \mathrm{C}$ \\
\hline Condensing temperature & $T_{C D}$ & $30{ }^{\circ} \mathrm{C}$ \\
\hline Maximum generation temperature & $T_{G}$ & $90{ }^{\circ} \mathrm{C}$ \\
\hline Adiabatic efficiency of the turbine & $\eta_{T}$ & 0.9 \\
\hline Adiabatic efficiency of the compressor & $\eta_{C}$ & 0.85 \\
\hline Mechanical efficiency of the block & $\eta_{M E C H}$ & 0.97 \\
\hline
\end{tabular}

The temperature regime corresponded to the real conditions of the refrigerating machine operation in the fruit storage [11], the maximum generation temperature corresponded to the conditions of operation of the waste heat of the small power machine. In accordance with equation (1), the minimum theoretical generation temperature was $77^{\circ} \mathrm{C}$. For simplicity of calculations, the difference in temperatures for heat transfer in the processes of heat supply and removal was taken equal to zero.

Calculations of the cycle parameters and characteristics were performed in accordance with equations (4) to (13), 
thermal characteristics of the block in accordance with equations (14) to (16), the design values of the block in accordance with [7].

The example contains solution of two problems.

Problem 1. Determination of the machine characteristics at constant cooling capacity $Q_{0}=115 \mathrm{~kW}$ and design values of the block (Fig. 3).

The calculation results are shown graphically in Fig. 4-7.

Fig. 4 shows pressures of evaporating $\left(p_{0}\right)$ and condensing $\left(p_{c d}\right)$ of the working fluids in the operating regime. The dashed line in the graph corresponds to a pressure of $0.1 \mathrm{MPa}$ which is the minimum allowable evaporating pressure sufficient to prevent hydrolysis of the working fluids.

The recommended working fluids in descending order are R401a, R134a, R290, R717, R407a, R507. It is not recommended to use R410a and $\mathrm{R} 600$.

The peripheral speed of the compressor runner (Fig. 5) is limited by the strength conditions and the possibility of supersonic speeds in various sections of the air-gas channel at which compression jumps are inevitable and accompanied by a significant increase in energy losses. An acceptable speed limit for selection of working fluids can be assumed to be $320-350 \mathrm{~m} / \mathrm{s}$ [7] Then it is rational to use R507, R134a, R407a, R401a, R410a.

Fig. 6 shows values of theoretical coefficients of conversion of the $C O P$ cycles obtained in calculations. Working fluids R134a, R290 and R600 are the most effective in the considered regime. The low $C O P$ values correspond to R410a, R407a, R507, R717.

Problem 2. Determination of the machine characteristics at constant design values of the block (Fig. 3) and constant shaft speed $n=460 \mathrm{~s}^{-1}$ [7].

The results of calculations are shown graphically in Fig. 7-9.

Fig. 7 shows values of cooling capacity of the machine. As can be seen from the figure, capacity of the centrifugal compressor can be changed several times at the same rotational speed by an appropriate selection of the working fluids. The use of working fluids R134a，R401a，R407a，R507，R600 makes it possible to reduce cooling capacity of the single-stage compression machines up to $15 \mathrm{~kW}$, even at moderately high rotational speeds. This reduces the machine efficiency (Fig. 8).

Fig. 9 shows the results of calculation of the equilibrium criterion $(P)$.

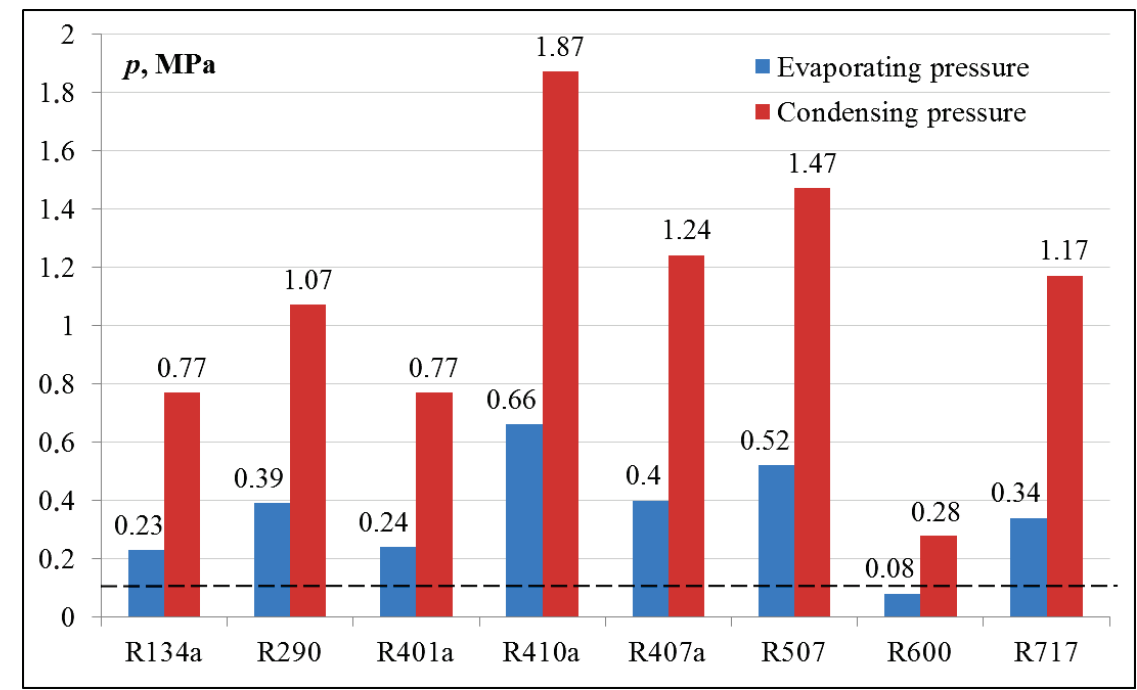

Fig. 4. Evaporating $\left(p_{0}\right)$ and condensing $\left(p_{c d}\right)$ pressures of working fluids in the operating regime

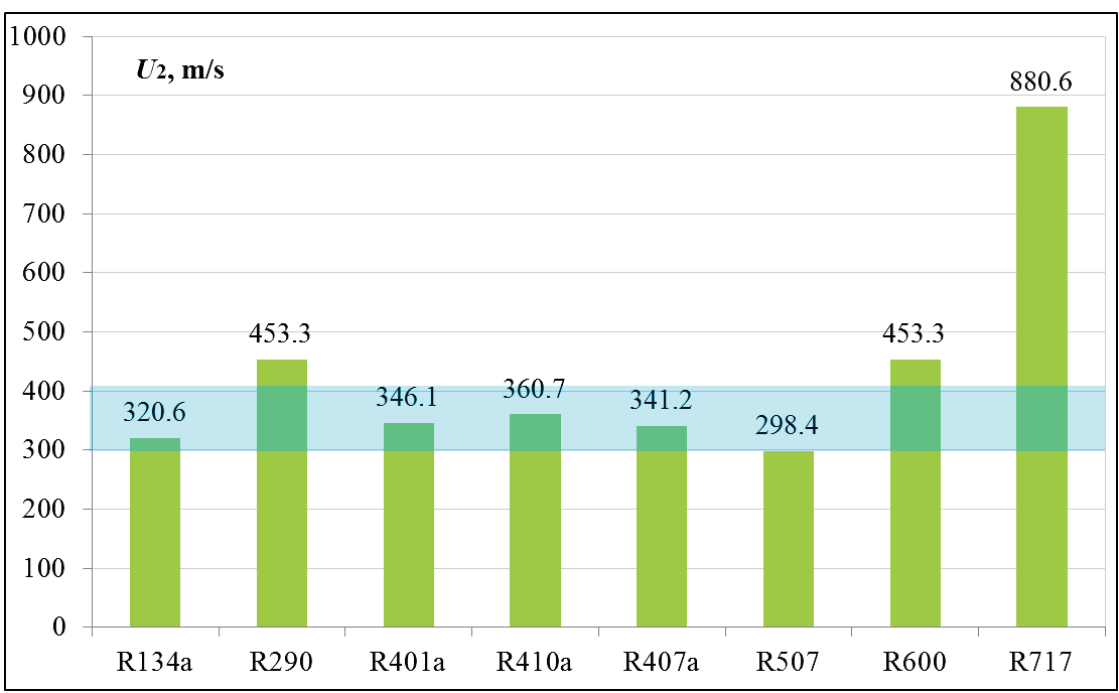

Fig. 5. Peripheral speed $U_{2}$ of the working fluids at the outlet from the compressor runner (problem 1)

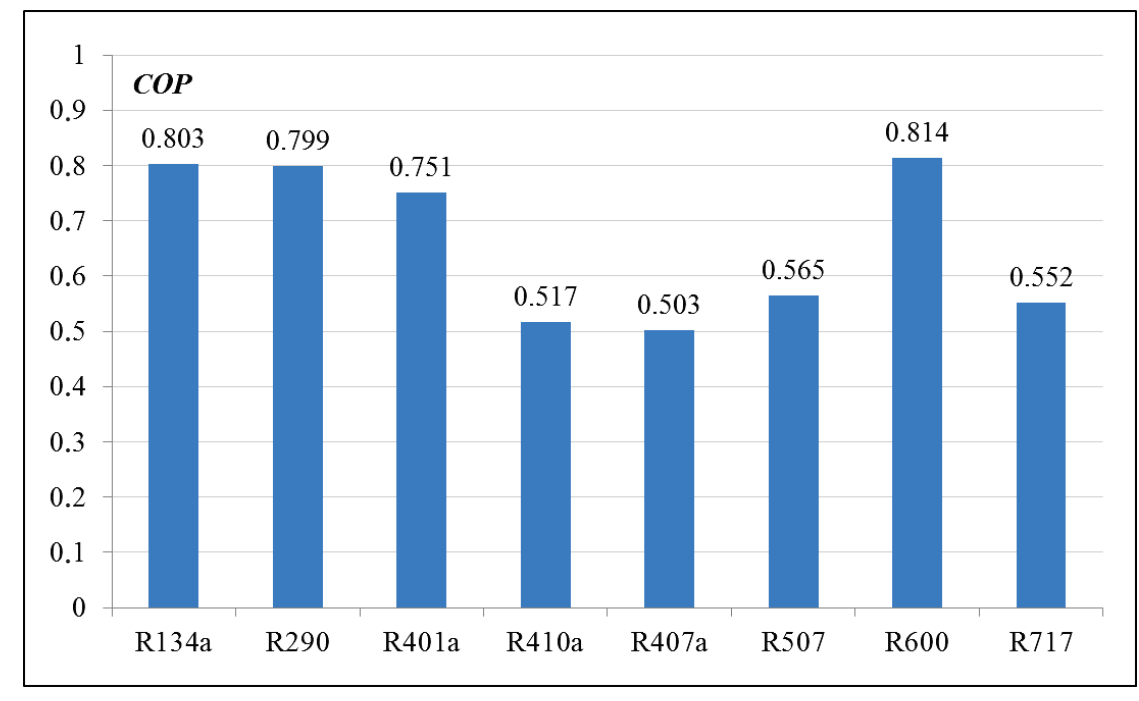

Fig. 6. Coefficient of conversion of the cycle $\operatorname{COP}$ (problem 1) 
The characteristic of the block design values is a constant value and is equal to 0.801 for this model (dash-dot line in the graph). The characteristics of various working fluids in the given temperature range of the thermodynamic cycle (Fig. 9, the shaded field of the graph) show that the machine with the working fluids R134a, R290, R401a, R507 can be realized in the fruit storage cooling system. The remaining working fluids for the conditions considered are inexpedient to use.

Of the design values and characteristics obtained in solving the problems, only a few were shown. They clearly define relationship between the working fluids and the compressor and turbine designs.

It is possible to abandon irrational solutions without making complex calculations.

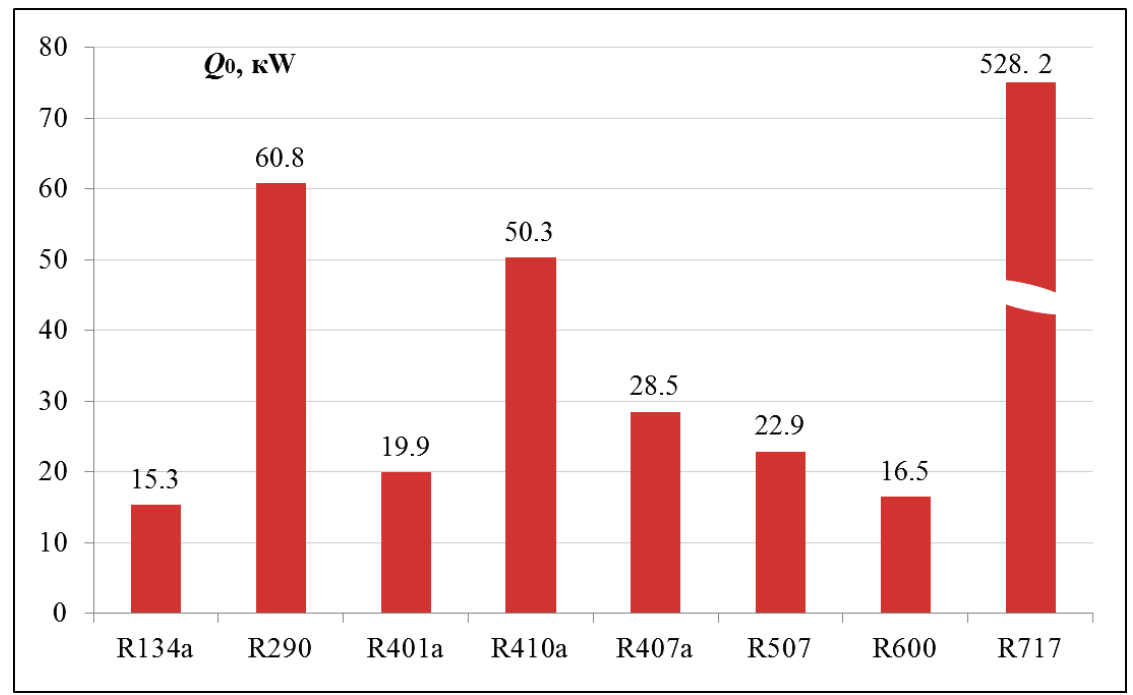

Fig. 7. Cooling capacity, $Q_{0}$, of the machine (problem 2)



Fig. 8. Coefficient of the cycle conversion $C O P$ (problem 2)

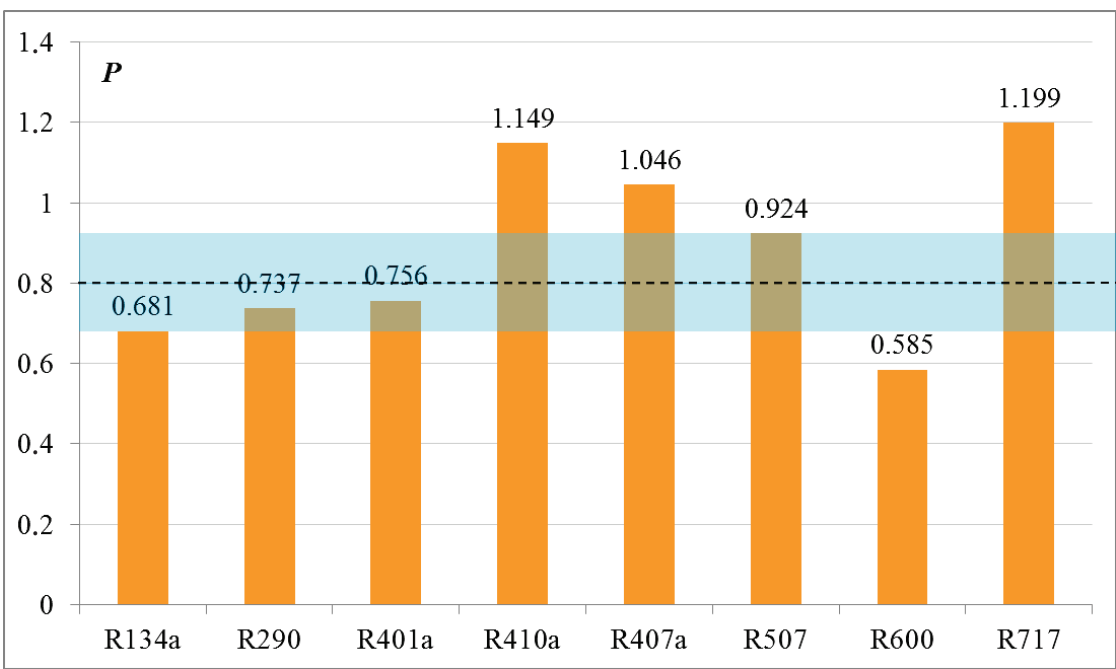

Fig. 9. Results of calculation of the equilibrium criterion, $P$

\section{Discussion of the results of selection of working fluids}

Theoretical studies of selection of working fluids have shown existence of several mandatory conditions. They are availability of a group of working fluids that can make an alternative to each other, cold consumer, design values of a full-scale sample of the turbine-compressor block and the results of its experimental studies. During the studies, advantages and disadvantages of all fluids were determined for a same operating regime. All working fluids correspond to the requirements of the service reliability of the machines $\left(p_{0} \leq 0.1 \mathrm{MPa}\right.$ and $\left.p_{c d} \leq 2.0 \mathrm{MPa}\right)$, the degree of increase in pressure $p_{c d} / p_{0} \approx 3.0$ corresponds to a single-stage compression. At a constant cooling capacity of the machine, the mass flow through the compressor and the peripheral speeds at the exit from the runners were established. High peripheral speeds gave grounds for exclusion of ammonia from the comparative analysis.

The studies using experimental data of the block with a same speed of rotation of the shaft for all fluids have shown the possibility of selection of a working fluids taking into account the necessary cooling capacity. The experimental data given in [17] have shown that the value of the complex characterizing the design values of the runners for single-stage blocks varies between 0.08 and 1.65. The theoretical results obtained for the complex characterizing the thermodynamic cycle have demonstrated potential applicability of the considered working fluids 
in the heat-using machines with turbine-compressor blocks and that experimental studies are required no more.

The use of a single block design and one cooling object in a trigeneration system for the studies has limited availability of more information on capabilities of the compression machines. The presented results can be considered the beginning of a study of low-capacity heat-using compression machines. Further development of the studies should be directed to the search for new cooling objects and new working fluids while maintaining the existing design of the turbine-compressor block.

\section{Conclusions}

1. The thermodynamic analysis of the Chistiakov-Plotnikov cycle for a given temperature regime has established working pressure limits $\left(p_{0} \leq 0.1 \mathrm{MPa}\right.$ and $\left.p_{c d} \leq 2.0 \mathrm{MPa}\right)$ and speed characteristics for working fluids in the compressor $(320 \ldots 350 \mathrm{~m} / \mathrm{s})$ ensuring operational reliability and energy efficiency of the whole machine. It is rational to use R507, R134a, R407a, R401a, R410a for these conditions.

2. The results of analysis of characteristics of the turbine and compressor as independent components of the machine are the basis for determining multiplicity of circulation of the working fluids in the refrigerating and power cycles of the machine. The optimum value is $a=1.0$ which is typical for the cycles with R134a, R290, R401a, R507 working fluids.

3. Introduction of the dimensionless equilibrium criterion makes it possible to evaluate dependence of the design values of the block on thermodynamic properties of the working fluids, conditions of its operation and the field of rational application of any working fluids for a particular design of the block. For the example considered, the working fluids R134a, R290, R401a, R507 satisfy the equilibrium conditions.

\section{References}

1. A contribution to the evaluation of the economic perspectives of absorption chillers / Berlitz T., Satzger P., Summerer F., Ziegler F., Alefeld G. // International Journal of Refrigeration. 1999. Vol. 22, Issue 1. P. 67-76. doi: https://doi.org/10.1016/ s0140-7007(98)00040-1

2. Thermal performance of a diffusion absorption refrigeration system driven by waste heat from diesel engine exhaust gases / Aly W. I. A., Abdo M., Bedair G., Hassaneen A. E. // Applied Thermal Engineering. 2017. Vol. 114. P. 621-630. doi: https:// doi.org/10.1016/j.applthermaleng.2016.12.019

3. Chen Y., Han W., Jin H. Analysis of an absorption/absorption-compression refrigeration system for heat sources with large temperature change // Energy Conversion and Management. 2016. Vol. 113. P. 153-164. doi: https://doi.org/10.1016/ j.enconman.2016.01.063

4. Analysis on innovative resorption cycle for power and refrigeration cogeneration / Jiang L., Roskilly A. P., Wang R. Z., Wang L. W. // Applied Energy. 2018. Vol. 218. P. 10-21. doi: https://doi.org/10.1016/j.apenergy.2018.02.174

5. Theoretical analysis and optimization of a hybrid CO 2 transcritical mechanical compression - ejector cooling cycle / Chen G., Volovyk O., Zhu D., Ierin V., Shestopalov K. // International Journal of Refrigeration. 2017. Vol. 74. P. 86-94. doi: https:// doi.org/10.1016/j.ijrefrig.2016.10.002

6. Petrenko V. O., Huang B. J., Ierin V. O. Design-theoretical study of cascade CO2 sub-critical mechanical compression/butane ejector cooling cycle // International Journal of Refrigeration. 2011. Vol. 34, Issue 7. P. 1649-1656. doi: https://doi.org/10.1016/ j.ijrefrig.2010.11.012

7. Barenboym A. B. Maloraskhodnye freonovye turbokompressory: monografiya. Moscow: Mashinostroenie, 1974. 224 p.

8. Barenboym A. B. Maloraskhodnye turbokompressory dlya kondicionirovaniya vozduha i ohlazhdeniya apparatury v transporte: monografiya. Odessa: Studiya «Negociant», 2000. 265 p.

9. Barenboym A. B. Turbomashiny dlya ohlazhdeniya nadduvochnogo vozduha dvigateley vnutrennego sgoraniya: monografiya. Odessa: Studiya «Negociant», 2001. 98 p.

10. Barenboym A. B. Holodil'nye centrobezhnye kompressory: monografiya. Odessa, 2004. 208 p.

11. Barenboim A. B., Morosuk T. V., Morosuk L. I. Heat - using refrigeration machines for agriculture // Refrigeration science and technology. 1998. Vol. 6. P. 216-220.

12. Morozyuk L. I., Morozyuk T. V., Gayduk S. V. Thermodynamic analysis of heat-energized refrigeration machine with carbon dioxide // Eastern-European Journal of Enterprise Technologies. 2014. Vol. 2, Issue 8 (68). P. 36-44. doi: https:// doi.org/10.15587/1729-4061.2014.22990

13. Moroziuk L. I., Haiduk S. V., Hrudka B. H. Analysis of the schematics of the compression heat-driven refrigeration machine with R744 // Eastern-European Journal of Enterprise Technologies. 2016. Vol. 1, Issue 8 (79). P. 29-39. doi: https:// doi.org/10.15587/1729-4061.2016.59470

14. Low-Temperature Heat-Driven Compression Refrigeration Machines with R744 / Morosuk L. I., Gaiduk S. V., Grudka B. G., Korzhuk D. V. // Refrigeration engineering and technology. 2017. Vol. 53, Issue 2. P. 4-13. doi: https://doi.org/10.15673/ret.v53i2.588

15. Study of a tri-generation system based on a supercritical $\mathrm{CO}_{2}$ cycle / Morosuk T. et. al. // Proceedings 1st European Seminar on Supercritical $\mathrm{CO}_{2}\left(\mathrm{sCO}_{2}\right)$ Power Systems. Vienna, 2016.

16. Stirlin H. Beitragzumtheorie der absorption-kaeltemaschintn // Kaeltechnik 16. 1964.

17. Morozyuk T. V. Teoriya holodil'nyh mashin i teplovyh nasosov: monografiya. Odessa: Studiya «Negociant», 2006.712 p. 